\title{
Presentation and Discussion of an Evaluation Model for Transdisciplinary Research Projects
}

\author{
Rebecca Schulte ${ }^{1}$ and Andrea Heilmann ${ }^{1}$
}

\begin{abstract}
In 2001 the academic advisory council for global environmental changes published the social contract for the big transformation. They demand a worldwide sustainable change in economics and society. Transdisciplinary research (TDR) should support the transformation e.g. by participatory research, learning and knowledge production for successful real-world-projects and knowledge sharing by transformative education. Particularly in connection with the demand for a third mission in universities, the major transformation of the society and the pursuit of sustainable development, it might surprise there is still no balance between Mode-2-Science, which TDR is a part of, and the monodisciplinary Mode-1-Science. In literature various examples of a punctual or in part projectaccompanying evaluation of TDR can be found, but however, the crucial long-term consequences of these projects are often not taken into consideration here - although they are required by many authors. Regarding the increasing importance of a third mission for universities, an increase in the meaning of TDR projects is expected. Therefore, new tools and methods are needed. In this paper an evaluation model is presented and applied that enables a project-related evaluation of TDR as well as sustainable third mission projects. The first use of the evaluation model and the quality criteria for research are presented and discussed.
\end{abstract}

Keywords: Transdisciplinary Research, Transdisciplinarity, Evaluation, Transformation, Sustainability

\section{Introduction}

At least since the Mode-3-Science in 2013 (Schneidewind\&Singer-Brodowski 2013), but rather since the introduction of Mode-2-Science in 1994 (März\&Bierwirth 2016) TDR has been an integral part of the scientific world. The demand for a major transformation of society, e. g. in the form of the developed two-degree-climaterestriction (UN-climate change conference Cancún) and the academic advisory council for global environmental changes require for a worldwide sustainable change in economics and society (WBGU 2011), accentuating the importance of TDR. The reasons for it are the pursuit of sustainable development and the definition of TDR as an instrument for the transformation (Krainer\&Winiwarter 2016). Participatory research (Nanz,Renn\&Lawrence 2017) and knowledge sharing (WBGU 2011) are examples of how TDR supports this transformation. Because of the lack of a generally accepted definition of TDR and the lack of holistic evaluation options for these projects, TDR is not as common as it could be (Krainer\&Winiwarter 2016, Jahn\&Keil 2015 and Belcher et al. 2016). The increasing importance of the universities' third mission might be a useful instrument to intensify the popularity of TDR. Therefore, it will be necessary to define third mission, sustainability, TDR and their conjunction. Furthermore, by evaluating TDR projects, the crucial long-term-consequences are often not taken into 
consideration, but they are required by experts (Bergmann et al. 2005) (DiIacovo 2016). To measure the long-term-consequences of TDR is also important to the stakeholders, therefore it could be useful to uncover the impact of universities' third mission. Aim of this research is therefore to present a definition of TDR, its position in the universities' context and request the portability of the requirement of sustainability in TDR projects on the universities' third mission. Furthermore, a model is presented, that enables a project-related evaluation. The crucial long-term-effects and the contribution to the transformation will be part of this model.

\section{Definitions}

The paper deals with "transdisciplinary, third mission and sustainability". Unfortunately, these terms are not consistently defined and in many cases used synonymously. The following definitions describe the applied ones.

\subsection{Transdisciplinary Research (TDR)}

By analyzing literature, many different definitions of TDR can be found. E.g. Pohl describes three categories (A, B, C) of definitions of TDR, composed by four features in different combination (Pohl 2011):

1. Category A

a. Relating to socially relevant problems

b. Transcending/integrating disciplinary paradigms

2. Category B

a. Relating to socially relevant problems

b. Transcending/integrating disciplinary paradigms;

c. Participatory research

3. Category C

a. Relating to socially relevant problems

b. Transcending/integrating disciplinary paradigms;

c. Unity of knowledge

As seen in the listing, there are disagreements and agreements between the categories and therefore between their representatives. Following on these, a definition of TDR is chosen by analyzing the literature. Finally, TDR is defined as a combination of Pohl's categories B and C (Pohl 2011) or as a combination of the two different definitions Karin Cronin presented in 2008 (Cronin 2008) - which are pretty similar to each other: In transdisciplinary research those research activities are defined as those that deal with a lifeworld problem within an interdisciplinary team. The researchers are working in cooperation with people who are affected by this lifeworld problem - the stakeholders - who provide the necessary practical knowledge and are involved in the research process. The intensity of cooperation depends on the type of project and can therefore be subject to fluctuations. In the course of this cooperative research, it is possible to create (transcend) an amount of knowledge and understanding that goes beyond the various disciplines, which is used to solve the problem or that can make a positive contribution to coping with future problems (knowledge platform or knowledge unit). 


\subsection{Third Mission}

The term "third mission" is defined by many different authors, e. g. Vorley \& Nelles (2008) or Pasternack \& Zierold (2015). Therefore, some of them are addressing the same aspects, such as economic and societal focus (Vorley\&Nelles 2008) or the context to teaching and research (Pasternack\&Zierold 2015). A subproject of the project TransInno_LSA 1 , part of the funding initiative "Innovative Hochschule" 2 , invented its own definition of third mission, which is mainly influenced by the definition of Pasternack \& Zierold (2015) but more specific. This definition will be used for this article.

'Third Mission is defined as a university's activity, which fulfills the following requirements: It is

1. relating to university's core processes - teaching and research - or their strategic aims.

2. making use of the university's resources, e. g. professors, students or rooms.

3. shaping the university's non-academic environment, e. g. by cooperative activities with non-academic agents. "'3

\subsection{Sustainability}

The commission of inquiry for „Schutz des Menschen und der Umwelt” by the German Bundestag presented a three-column-model for sustainable development in 1995 (WDDB 2004). The model is based on the report "Our Common Future" of the Brundtland-Commission in 1987, priority (WDDB 2004). The commission defined sustainability as

"meeting the needs of the present without compromising the ability of future generations to meet their own needs."

The model includes balanced aims in social, ecologic and economic aspects and therefore it emphasizes the importance of interdisciplinarity in sustainability. In order to address the sustainability goals, it will be necessary to build new transdisciplinary cooperations.

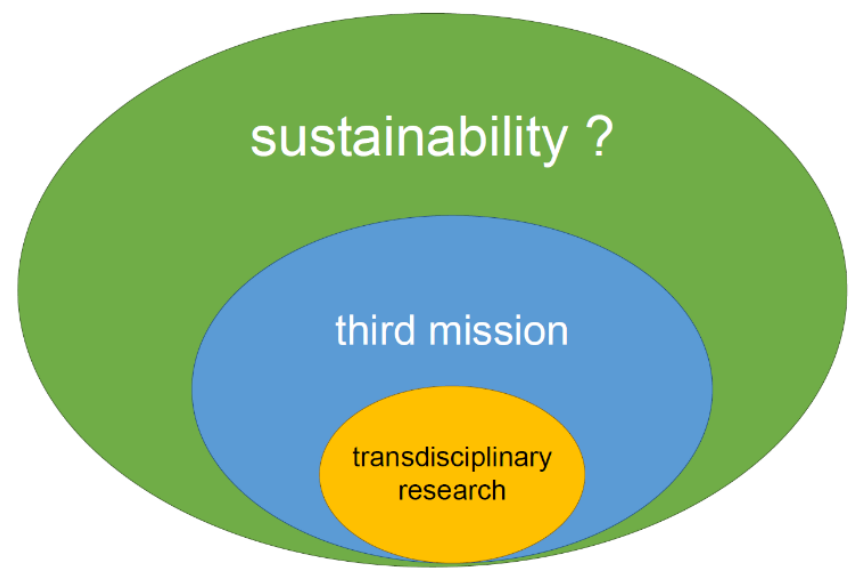

Figure 1: TDR as part of third mission and sustainability.

\footnotetext{
${ }_{1}^{1}$ More information: https://www.transinno-lsa.de.

2 More information: https://www.innovative-hochschule.de.

3 TransInno_LSA 2019, own translation of the original.
} 
As TDR, third mission and sustainability are defined above, they are mutually coherent. From the picture below it is clear that TDR is a part of the universities' third mission. It is relating to the universities' core process research, using the resources (e. g. professors). It is also shaping the non-academic environment by a cooperative activity with the citizens.

By using TDR as an instrument for transformation processes towards a sustainable society (Krainer\& Winiwarter 2016, Schneidewind\&Singer-Brodowski 2013), TDR can be considered as part of sustainabilty. But what about third mission? Is sustainability a necessity for all of its activities? The third requirement, shaping the non-academic environment, points out the involvement of non-academic agents, like stakeholders. These citiziens are surely just interested in working on projects which may help them to improve their own situation but which are also not going to destroy their children's future. So third mission may be sustainable by definition. This is just a conjunction. Future analysis of existing Third-Mission-Activities may prove or disaprove their usefulness. As part of the universities' third mission, transdisciplinary research could surely become more known and important for these institutions.

\section{Development of an Evaluation Model for TDR}

To gather the state of the art in the evaluation of transdisciplinary projects and therefore the knowledge and experiences of experts, a systematical research and a focusgroup-discussion were used. The experts' opinions are combined with the research results to develop the criteria for the evaluation model (please see figure 2). In following (Table 1) the used literature for the identification of criteria is presented. The identified criteria for a successful TDR-project are allocated to the four phases of the model.

Table 1: References used for the evaluation model.

\begin{tabular}{|c|c|}
\hline Criteria & Literature \\
\hline Transdisciplinary & Bergmann et al. (2005) and Klenk \& Meehan (2015) \\
\hline $\begin{array}{l}\text { Project's } \\
\text { parameters }\end{array}$ & $\begin{array}{l}\text { Bergmann et al. (2005), Van Drooge \& Spapen (2017), Di Iacovo (2016), } \\
\text { Holzer, Carmon \& Orenstein (2018) and Klenk \& Meehan (2015) }\end{array}$ \\
\hline Content aims & $\begin{array}{l}\text { Bergmann et al. (2005), Di Iacovo (2016) and the Focus-group-discussion } \\
\text { (Schulte 2018) }\end{array}$ \\
\hline Sustainability & $\begin{array}{l}\text { 2004), WBGU (2011), Bergmann et al. (2005) and the Focus-group- } \\
\text { (Schulte 2018) }\end{array}$ \\
\hline Partic & 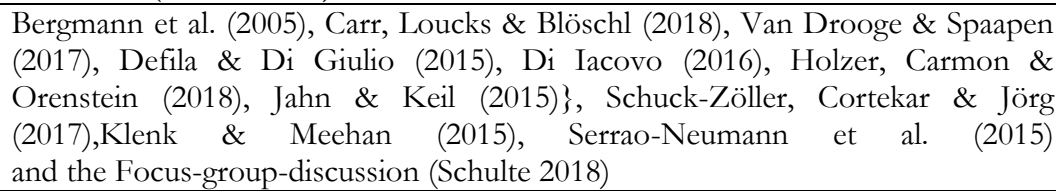 \\
\hline it & $\begin{array}{l}\text { n et al. (2005), Defila \& Di Giulio (2015), Di Iacovo (2016), Klenk \& } \\
(2015) \text { and Serrao-Neumann et al. (2015). }\end{array}$ \\
\hline Reliability & $\begin{array}{l}\text { elcher et al. (2016), Serrao-Neumann et al. (2015) and the Focus-group- } \\
\text { iscussion (Schulte 2018). }\end{array}$ \\
\hline Legitimacy & $\begin{array}{l}\text { Belcher et al. (2016), Carr, Loucks \& Blöschl (2018), Holzer, Carmon \& } \\
\text { Orenstein (2018), Klenk \& Meehan (2015), Schuck-Zöller, Cortekar \& Jörg } \\
\text { (2017), Serrao-Neumann et al. (2015), Walter et al. (2007) and the Focus-group- } \\
\text { discussion (Schulte 2018). }\end{array}$ \\
\hline $\begin{array}{l}\text { roducts } \\
\text { ols }\end{array}$ & $\begin{array}{l}\text { ann et al. (2005), Carr, Loucks \& Blöschl (2018), Holzer, Carmon \& } \\
\text { tein (2018), Jahn \& Keil (2015), Schuck-Zöller, Cortekar \& Jörg (2017). }\end{array}$ \\
\hline
\end{tabular}




\begin{tabular}{ll}
\hline $\begin{array}{l}\text { Outcome } \\
\text { research } \\
\text { education }\end{array}$ & $\begin{array}{r}\text { in Bergmann et al. (2005), Carr, Loucks \& Blöschl (2018), Holzer, Carmon \& } \\
\text { and Orenstein (2018), Schuck-Zöller, Cortekar \& Jörg (2017), Serrao-Neumann } \\
\text { (2015) and Walter et al. (2007). }\end{array}$ \\
\hline \multirow{2}{*}{ Learning } & $\begin{array}{l}\text { Belcher et al. (2016), Carr, Loucks \& Blöschl (2018), Defila \& Di Giulio (2015), } \\
\text { Di Iacovo (2016), Holzer, Carmon \& Orenstein (2018), Jahn \& Keil (2015), } \\
\text { Klenk \& Meehan (2015), Serrao-Neumann (2015), Van Drooge \& Spaapen } \\
\text { (2017), Walter et al. (2007) and the Focus-group-discussion (Schulte 2018). }\end{array}$ \\
\hline \multirow{2}{*}{ Happiness } & $\begin{array}{l}\text { Bergmann et al. (2005), Van Drooge \& (2017), Holzer, Carmon \& Orenstein } \\
\text { (2018), Jahn \& Keil (2015) and the Focus-group-discussion (Schulte 2018). }\end{array}$ \\
\hline \multirow{2}{*}{ Transformation } & $\begin{array}{l}\text { Bergmann et al. (2005), Belcher et al. (2016), Defila \& Di Giulio (2015), Holzer, } \\
\text { Carmon \& Orenstein (2018), Jahn \& Keil (2015), Krainer \& Winiwarter (2016), } \\
\text { Walter et al. (2007) \& the Focus-group-discussion (Schulte 2008). }\end{array}$
\end{tabular}

The evaluation model is parted in four phases which will be processed during the project. Every phase includes different criteria (compiled in table 1), although the criteria sustainability is part of every phase.

Figure 2 provides information on every phase as well as a review about the structure and the needed information.

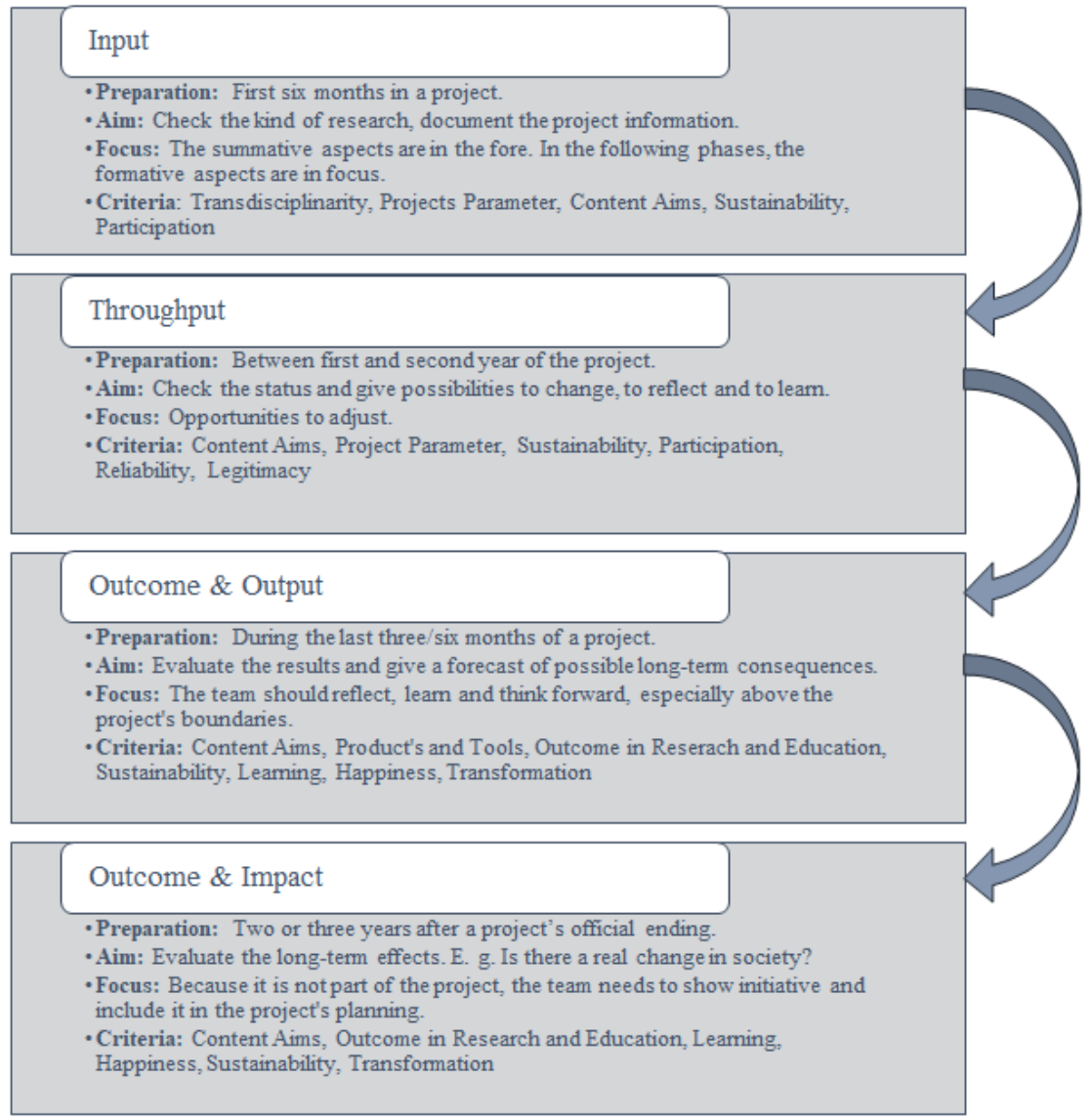

Figure 1: Phases of the Evaluation Model for Transdisciplinary Research Projects. 
Exemplarily phase four will be looked at. This phase is special in the model, because its existence is regarded by authors (e. g. Bergmann et al. 2005 and Di Iacovo 2016), even though just a few of them offer own examples in their models.

Phase four, "Outcome and Impact", is located some years after the project's ending. The aim is to have a look at the crucial long-term effects. Examples of these effects are the project's contribution to the transformation (criteria Transformation), the stakeholder's happiness with the established and refined solutions (criteria Content Aims and Happiness) as well as the learned methods, tools or procedures the members could use in further projects (criteria Learning).

In figure 3 the fourth phase is presented. The criteria are represented as oval-figures, the sub-criteria as rectangle. The arrows document the symbolic flow of information and the order to work on the criteria.

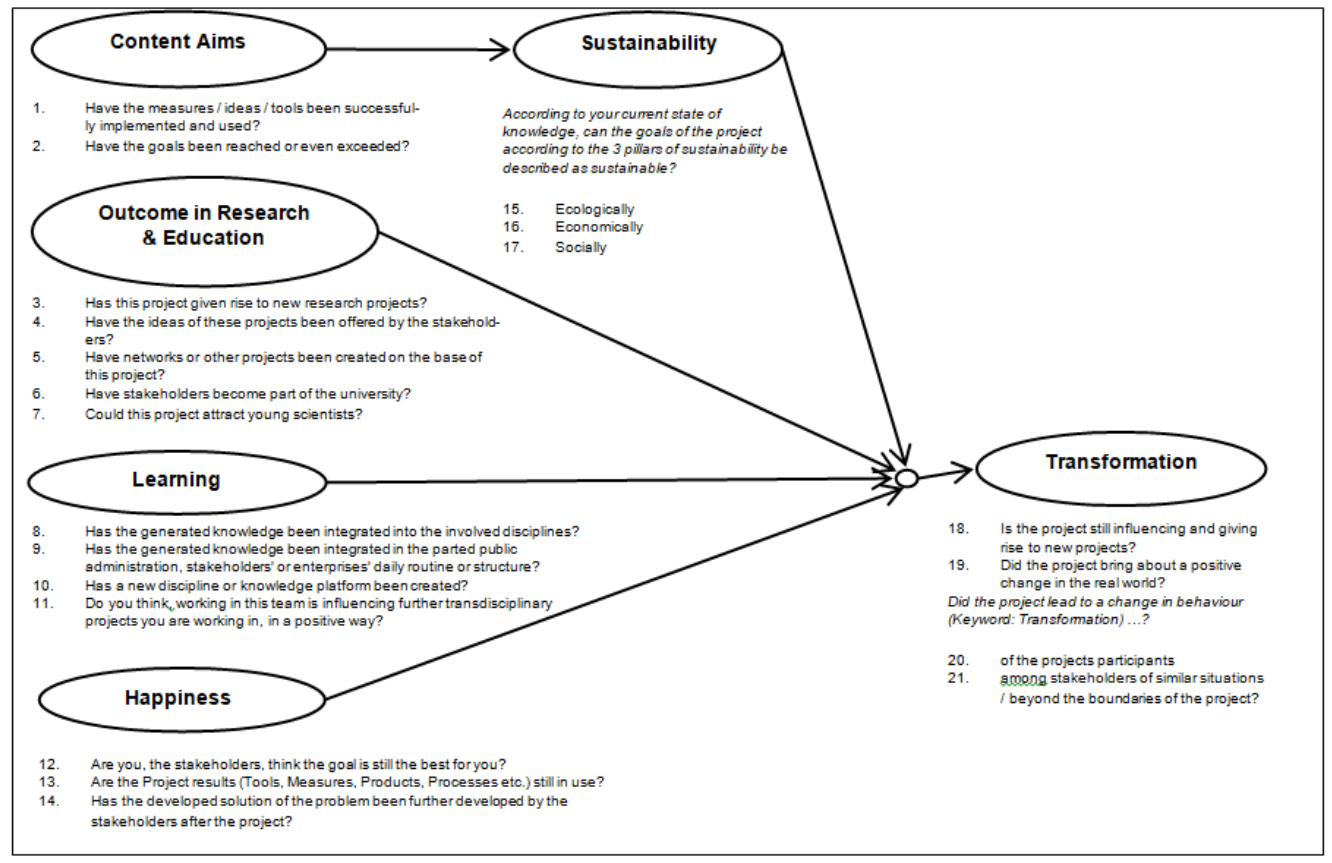

Figure 2: Evaluation model Phase 4: Impact \& Outcome.

\section{First Application and Validation of the Model}

\subsection{The case study "Community shop / Dorfladen"}

The following first application on the case study "Community shop/ Dorfladen" 4 is used as the first validation. The case study itself can be considered as a TDR project.

${ }^{4}$ The project was sponsored by the Federal Ministry of Education and Research (first period between June 2012 and July 2013) and the Federal Ministry of Food and Agriculture (second period between September 2014 and August 2015). 
Bergmann et. al (2005) described an ideal transdisciplinary research process which has also been applied for the case study. Characteristic for the process is the differentiation of the general research object in sub-questions. The general question was the identification of a viable concept for a community shop. Sub-questions were addressed as logistical, economic as well as organizational questions. The sub-questions are worked on in teams. These sub-teams consist of researchers including students as well as of citizens and practitioners. The essential perceptions are made available to all other stakeholders for discussion and further usage (integration). Therefore, an open website was used. The project management ensures the compatibility between the various parts of the project. Finally, impulses are expected for changes in practice and innovations in science (intervention). The role of digitalization in rural areas was pointed out as an example topic of a future work. The project was scientifically assisted by the Harz University of Applied Sciences ${ }^{5}$.

Main characteristics of the case study meet the following criteria according to Bergmann et al. 2005) which are:

- Problem orientation and translation - examine everyday life problems to shape real processes:

The research project was concentrated on the following question: "How to provide daily goods in a rural area? Can social relationships be improved? Continuous networking was given through regular project meetings and the project's own participation platform www.vision20plus.de.

- Stakeholder orientation:

The stakeholders who have been involved in the project mainly consisted of interested inhabitants and local authorities. They had a strong influence by defining research and development goals, by providing information, by taking responsibility for the implementation and participating in the evaluation.

- Context-relatedness:

An essential aspect of the case study was the consideration of the specific regional conditions and specifications like the impact of demographic changes, logistic aspects in a rural area and the existing supply.

The project also meets criteria for sustainability because it improves the social and economic situation of inhabitants and it contributes to better living conditions in rural areas.

Since resources of the Hochschule Harz are provided it can also be considered as a Third Mission Project.

This project was also chosen because the project's experts are locals and because it was finished three years ago, so the long-term-effects can be evaluated. Therefore, the first three phases of the evaluation model will be processed retrospectively. Due to an easier evaluation, the break between first and second period is faded out. Please note: For the evaluation it should be considered that this project is described as successful by the users. It is part of the evaluation to prove or to disprove this subjective grading.

\footnotetext{
5 For more information about the project please check the webpage: www.zukunftswerkstatt.li/users/dorfladen.
} 


\subsection{Results for Project and Model}

The Project. Three former project members will prepare and discuss the evaluation: one professor, one research assistant and one stakeholder. Henceforth they will also be called users or participants.

The presented model isn't manageable, therefore the criteria and sub-criteria will be prepared as a survey. This kind of preparation is easier to understand and manageable. The project "Dorfladen" receives 93.48\% (rounded 94\%), therefore a 1.3, very good (table 2). The subjective grading of the users is reflected.

Table 2: Allocation for each phase.

\begin{tabular}{llc}
\hline Phase & Scoring & Percent \\
\hline Input: & scoring 86.25 by 90 points & $95.83 \%$ \\
\hline Throughput: & scoring 90 by 90 points & $100 \%$ \\
\hline Outcome \& Output: & scoring 83.97 by 90 points & $93.10 \%$ \\
\hline Outcome \& Impact & scoring 76.5 by 90 points & $85 \%$ \\
\hline
\end{tabular}

As represented by the results, the case study "Community shop/ Dorfladen" did a very good job. Only few criteria were not fulfilled. In phase one, Input, the criteria Participation, sub-criteria 23, was not fulfilled, because the measureable aims were not developed together with the stakeholders. In phase three, Outcome \& Output, criteria Learning, sub-criteria 22 is not fulfilled, because there is no option for storage and transfer of the knowledge. Finally, the project couldn't attract young scientists by the project's environment (phase four, criteria Outcome in Research and Education, subcriteria 7), integrate the generated knowledge in parted disciplines or create a new way of knowledge (phase four, criteria Learning, sub-criteria 8 and 10).

The Model. Every use of the model could help to improve it. This will be seen as validation. The small changes in formulations (e. g. inaccuracies or room for interpretation) and smaller supplements, which were initiated by the first use, are already considered in the represented model. During the first use, there are some aspects of the model and the use which were discussed and need to be resolved during following usages.

Part of them was a Likert-scale, which would offer a more detailed analysis. By designing the model, this kind of evaluation was prioritized. Concerning the regression towards the mean (Wortmann 1983) and the easier processing for the users, finally the binary scale was chosen. Therefore, the regression could also be avoided by using a Six-Point-LikertScale. The request for another kind of scale than the binary one needs to be reviewed during further validation/usages. Also Flexibility might be extended by offering a choice between using a binary or a Likert-scale. Currently parts of the flexibility are changes in aims, the individual choice of singular phases or weight for criteria.

Using the model for the project "Dorfladen" was a retrospective evaluation. A disadvantage of working with "Dorfladen" was that this project had already been completed by the time the team decided to apply the model to it. As a consequence, the retrospective processing of sub-criteria 14 (Input, Content Aims) was difficult for the users. Fears and problems that usually come about with a new project did not have to be considered in the case of "Dorfladen". However, for the first validation of this model, 
there was a need for a project whose completion lay some years behind, because using the fourth phase would have otherwise been impossible. For future usages a way should be developed to eliminate the effects of a retrospective evaluation. This would offer more flexibility.

To refine the model and expose possible correlations, future usages are planned (e.g. TransInno_LSA, VTTNetz ${ }^{6}$. Possibilities for international usage should be checked. During the focus-group-discussion the idea of using agile methods to manage a TDR project came up. This idea is interesting; a project was announced at HS Harz. Aim of this project was to check the possibilities and challenges of using agile methods and tools for managing a TDR project.

As defined, TDR-projects are part of a university's third mission. Therefore, they might become more important in the future. An example is the presented project TransInno_LSA. The subproject TBT evolves a method (a toolbox) to measure and control the universities' Third-Mission-Activities (HarzUniversity 2017). The developed model could be part of this toolbox and help to evaluate a variety of projects. Therefore, the model would be used by every interested university as part of an instrument for controlling and quality management. Another example is the article of Kościelniak, Mickiewicz and Roemer (2013). The authors discuss the impact of sustainable development on universities' third mission.

\section{Summary}

This paper starts by presenting some necessary definitions and a discussion about coherences between transdisciplinary, third mission and sustainability. As defined, TDR needs to be sustainable and TDR is part of third mission. But the discussion about sustainability as a requirement for every other third-mission-activity is not finished at the moment and should be part of following researches.

Afterwards, a holistic model to evaluate TDR projects is visualized. This model could also be useful as part of an instrument for quality management and controlling for the universities' third mission and the role of transdisciplinarity and sustainability in it.

The first use of this model is performed on a subjectively successful project. The selected project "Community shop / Dorfladen" could meet the definitions of a TDR, Third Mission and Sustainable Project. The evaluation confirms the member's impressions of a successful project The application of the evaluation model is seen as a first validation, but further usages should follow to prove the model. Several aspects for improvement are identified for instance the integration of a Likert-scale or the consideration of retrospective evaluation. Considering the rising importance of Third Mission activities it should be proven to adapt the evaluation model.

\section{References}

Belcher, B. M. et al. (2016). Defining and assessing research quality in a transdisciplinary context. Research Evaluation, 25 (1), p. 1-17.

Bergmann, M. et al. (2005). Quality Criteria of Transdisciplinary Research. Frankfurt am Main: Institute for Social-Ecological Research (ISOE).

${ }^{6}$ More information: https://www.transinno-lsa.de/teilprojekte/vttnetz. 
Carr, G., Loucks, D. P. \& Blöschl, G. (2018). Gaining insight into interdisciplinary research and education programmes: A framework for evaluation. Research Policy, 47 (1), p. 35-48.

Cronin, K. (2008). Transdiciplinary research (TDR) and sustainability, Neuseeland: Institute of Environmental Science and Research Limited (ESR).

Defila, R. \& Di Giulio, A. (2015). Methodische Gestaltung transdisziplinärer Workshops. In N. M. \& W., S. (edt.), Methoden der Experten- und Stakeholdereinbindung in der sozialwissenschaftlichen Forschung (p. 69-93), Wiesbaden: Springer Fachmedien.

Di Iacovo, F. (2016). Measuring the effects of transdisciplinary research: the case of a social farming project. Futures, 75 , p. 24-35.

Holzer, J. M., Carmon, N. \& Orenstein, D. E. (2018). A methodology for evaluating transdisciplinary research on coupled socio-ecological systems. Ecological Indicators, 85, p. 808-819.

Jahn, T. \& Keil, F. (2015). An actor-specific guideline for quality assurance in transdisciplinary research. Futures, 65, p. $195-208$.

Klenk, N. \& Meehan, K. (2015). Climate change and transdisciplinary science: Problematizing the integration imperative. Environmental Science \& Policy, 54, p. 160-167.

Kościelniak, C., Mickiewicz, A. \& Roemer, R. (2013). Sustainable Development as a Part of the "Third Mission" of the Universities". Safety of Technogenic Environment, 2013/4, p. 24-29.

Krainer, L. \& Winiwarter, V. (2016). Die Universität als Akteurin der transformativen Wissenschaft: Konsequenzen für die Messung der Qualität transdisziplinärer Forschung. GAIA - Ecological Perspectives for Science and Society, 25 (2), p. 110-116.

März, S. \& Bierwirth, A. (2016). Transition-Forschung - Ein praxisorientierter Überblick. In H. L. \& R. J. (edt.), Energiewende und Partizipation. Transformationen von Gesellschaft und Technik. (p. 5771), Wiesbaden: Springer Fachmedien.

Nanz, P., Renn, O, \& Lawrence, M. (2017). Der transdisziplinäre Ansatz des Institute for Advanced Sustainability Studies (IASS): Konzept und Umsetzung. GAIA - Ecological Perspectives for Science and Society, 26 (3), p. 293-296.

Pasternack, P. \& Zierold, S. (2015). Strategieentwicklung trotz Hindernissen. Hochschul-aktivitäten und Bedarfslagen in schrumpfenden Regionen. In M. F., P. P. \& M. T. (edt.), Schrumpfende Regionen - dynamische Hochschulen. (p. 255-278), Wiesbaden: Springer Fachmedien.

Pohl, C. (2011). What is progress in transdisciplinary research? Futures, 43 (6), p. 618-626.

Schneidewind, U. \& Singer-Brodowski, M. (2013). Transformative Wissenschaft: Klimawandel im deutschen Wissenschafts- und Hochschulsystem. Marburg: Metropolis Verlag.

Schuck-Zöller, S., Cortekar, J. \& Jacob, D. (2017). Evaluating co-creation of knowledge: from quality criteria and indicators to methods. Advances in Science and Research, 14, p. 305-312.

Schulte, R. (2018) Transkription der Foskugruppendiskussion an der Hochschule Harz. unveröffentlichtes Dokument, Wernigerode.

Serrao-Neumann, S. et al. (2015). One human settlement: A transdisciplinary approach to climate change adaptation research. Futures, 65, p. 97-109.

TransInno_LSA (2019). Definition für Third Mission. Available under https://www.transinnolsa.de/fileadmin/user_upload/Third_Mission_Definition.pdf.

Van Drooge, L. \& Spaapen, J. (2017). Evaluation and monitoring of transdisciplinary collaborations. The Journal of Technology Transfer, 538 (1), p. 1-15.

Vorley, T. \& Nelles, J. (2008). (Re)Conceptualising the Academy: Institutional Development of and beyond the Third Mission. Higher Education Management and Policy, 20 (3), p. 119-135.

Walter, A. et al. (2007). Measuring societal effects of transdisciplinary research projects: Design and application of an evaluation method. Evaluation and program planning, 30 (4), p. 325-338.

WBGU - Wissenschaftlicher Beirat der Bundesregierung Globale Umweltveränderungen (2011). Welt im Wandel. Gesellschaftsvertrag für eine Große Transformation. Berlin: WBGU.

WDDB - Wissenschaftliche Dienste des Deutschen Bundestages (2004). Nachhaltigkeit, Der aktuelle Begriff. 06/2004, online: https://www.bundestag.de/resource/blob/194082/f326b045 52483bbb9efad8b0fb0696d2/nachhaltigkeit-data.pdf.

Wortmann, P. M. (1983). Evaluation research - A methodological perspective. Annual Review of Psychology, 34 (1), p. 223-260.

TransInno_LSA is part of the "Innovative Hochschule" project. Funding: Federal Ministry of Education and Research (Germany) and Land Saxony-Anhalt. 